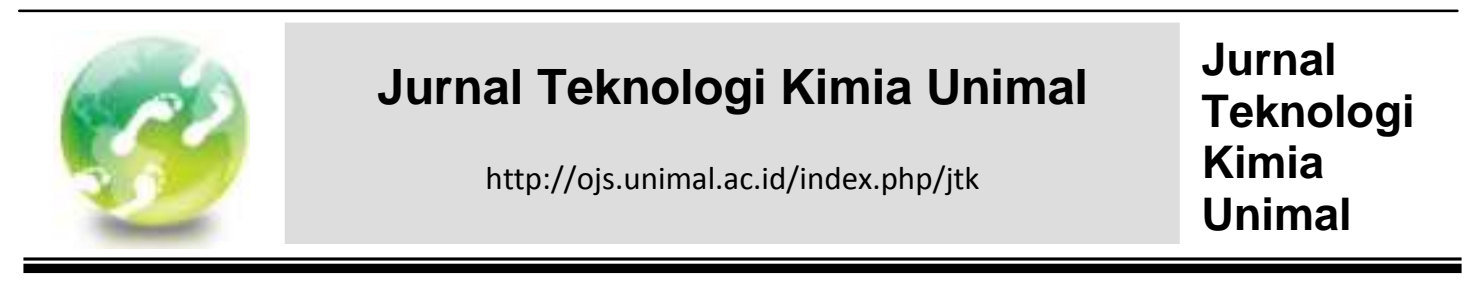

\title{
Proses Pembuatan Bioetanol dari Kulit Pisang Kepok (Musa acuminata B.C) secara Fermentasi
}

\author{
${ }^{1}$ Wusnah, ${ }^{2}$ Samsul Bahri, ${ }^{3}$ Dwi Hartono \\ 1,2,3 Jurusan Teknik Kimia, Fakultas Teknik, Universitas Malikussaleh \\ Lhokseumawe \\ email:wusnah@yahoo.com
}

\begin{abstract}
Abstrak
Kulit pisang kepok selama ini hanya dianggap sebagai salah satu limbah industri rumah tangga yang belum termanfaatkan dengan baik. Komposisi terbanyak kedua kulit pisang kepok adalah karbohidrat 18,50\% dimana karbohidrat dapat dikonversi menjadi glukosa yang selanjutnya dapat digunakan sebagai bahan baku pembuatan bioetanol.Penelitian ini bertujuan membuat bioethanol dari kulit pisang kepok dengan variasi waktu fermentasi dan penambahan starter. Pada penelitian ini kulit pisang kepok dihidrolisis dengan mengunakan $\mathrm{HCl} 5 \%$ pada suhu $100^{\circ} \mathrm{C}$ selama 60 menit. Hasil penelitian menunjukkan bahwa semakin lama waktu fermentasi maka semakin banyak etanol yang dihasilkan.Pada variasi waktu fermentasi diperoleh waktu terbaik fermentasi pada waktu 7 hari dengan kadar etanol $40 \%$ sebanyak $34 \mathrm{ml}$.
\end{abstract}

Kata kunci : kulit pisang kepok, bioetanol, fermentasi

\section{Pendahuluan}

Sumber daya energi konvensional bahan bakar fosil (minyak/gas bumi dan batu bara) sebagai sumber energi yang tidak terbarukan dengan segala permasalahannya, terutama kenaikan harga (price escalation) secara global setiap terjadinya krisis energi akibat dari faktor-faktor seperti cadangan yang berkurang sesuai dengan umur eksploitasinya, permintaan yang meningkat, jaminan pasokan (supply security) yang terbatas dan pembatasan produksi serta penilaian dampak lingkungan yang ketat terhadap pemanasan global (global warming), harus dikurangi ketergantungannya denganmenggunakan sumber-sumber energi lainnya sebagai bahan bakar alternatif.

Bioetanol merupakansalah satu sumber bahan bakar alternatif yang diolah dari tumbuhan, dimana memiliki keunggulan mampu menurunkan emisi $\mathrm{CO}_{2}$ 
hingga $18 \%$. Menurut Balai Besar Teknologi Pati (B2TP) ada 3 kelompok tanaman sumber bioetanol: tanaman yang mengandung pati (seperti singkong, kelapa sawit, tengkawang, kelapa, kapuk, jarak pagar, rambutan, sirsak, malapari, dan nyamplung), bergula (seperti tetes tebu atau molase, nira aren, nira tebu, dan nira surgum manis) dan serat selulosa (seperti batang sorgum, batang pisang, jerami, kayu, dan bagas). Kulit pisang merupakan limbah yang banyak mengandung serat selulosa sehingga sangatefisien digunakan dari pada buahnya yang memiliki nilai jual yang tinggi.

Beberapa penelitian pembuatan bioetanol dengan menggunanakan kulit pisang kepok pernah dilakukan sebelumnya. Nityasa (2009), pembuatan bioetanol dari kulit pisang dengan proses ekstraksi. $5 \mathrm{~kg}$ kulit pisang dihaluskan dan ditambahkan air 2/3 dari jumlah kulit pisang, sehingga diperoleh bubur kurang lebih 1,5 liter. Bubur dihidrolisis dengan penambahan $\mathrm{HCl} 10 \%$ pada temperatur $60^{\circ} \mathrm{C}$, yang selanjutnya difermentasi dengan bantuan Saccharomyces cereviceae pada temperatur $32^{\circ} \mathrm{C}$ sehingga dihasilkan $15 \%$ etanol per $1,5 \mathrm{~L}$ jumlah bubur.

Asteria (2013), kulit pisang dihidrolisis menggunakan laruan $\mathrm{HCl} 37 \%$ pada $\mathrm{pH}$ 1. Hidrolisis dilakukan pada suhu 50,60, 70, dan $80^{\circ} \mathrm{C}$ selama 1 jam. Selanjutnya difermentasikan dengan Saccharomyces cereviceae dengan variabel nutrien Diamonium phospat 10, 20, dan $30 \mathrm{gr} / 1$ selama 12 hari. Hasil penelitian menunjukkan glukosa optimum yang didapat dari hidrolisis adalah 83,021 gr/l pada suhu $70^{\circ} \mathrm{C}$ selama 1 jam. Kandungan bioetanol optimum didapat dari fermentasi hari ke-8 sebesar 314.46 gr etanol/kg kulit pisang kering.

Dyah (2011), kulit pisang yang digunakan adalah kulit pisang yang telah dikeringkan dan dihidrolisi menggunakan $\mathrm{H}_{2} \mathrm{SO}_{4} \quad 0,5 \quad \mathrm{~N}$. Hasil penelitian menunjukkan bahwa semakin lama fermentasi semakin banyak dihasilkan etanol sampai pada waktu tertentu dan semakin banyak ragi yang ditambahkan akan dihasilkan etanol semakin rendah. Pada variasi waktu fermentasi diperoleh waktu optimum fermentasi pada waktu 144 jam dengan kadar etanol 
13,5406\%. Pada variasi penambahan berat ragi diperoleh kadar etanol 13,5353\% dengan berat ragi 0,0624 gram.

Bioetanol adalah sebuah bahan bakar alternatif yang diolah dari tumbuhan, dimana memiliki keunggulan mampu menurunkan emisi $\mathrm{CO}_{2}$ hingga $18 \%$. Ada 3 kelompok tanaman sumber bioetanol: tanaman yang mengandung pati (seperti singkong, kelapa sawit, tengkawang, kelapa, kapuk, jarak pagar, rambutan, sirsak, malapari, dan nyamplung), bergula (seperti tetes tebu atau molase, nira aren, nira tebu, dan nira surgum manis) dan serat selulosa (seperti batang sorgum, batang pisang, jerami, kayu, dan bagas). Bahan yang mengandung pati, glukosa, dan serat selulosa ini bisa dimanfaatkan sebagai bahan bakar (Arif, 2011).

Tidak ada perbedaan antara etanol biasa dengan bioetanol yang membedakannya hanyalah bahan baku pembuatan dan proses pembuatannya. Etanol adalah sejenis cairan yang mudah menguap, mudah terbakar, tak berwarna, dan merupakan alkohol yang paling sering digunakan dalam kehidupan seharihari. Senyawa ini merupakan obat psikoaktif dan dapat ditemukan pada minuman beralkohol dan termometer modern. Etanol termasuk ke dalam alkohol rantai tunggal, dengan rumus kimia $\mathrm{C}_{2} \mathrm{H}_{5} \mathrm{OH}$ dan rumus empiris $\mathrm{C}_{2} \mathrm{H}_{6} \mathrm{O}$. Ia merupakan isomer konstitusional dari dimetil eter.

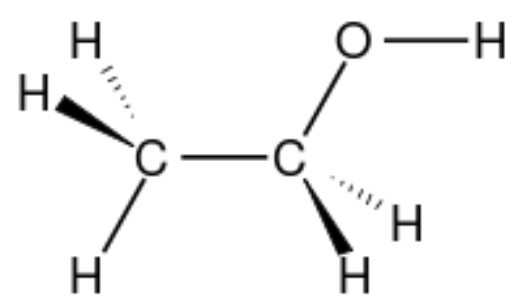

Gambar 1 Struktur Molekul Etanol

Bioetanol yang digunakan sebagai campuran bahan bakar merupakan etanol (etil alcohol) dengan jenis yang sama dengan yang ditemukanpada minuman beralkohol. Etanol seringkali dijadikan bahan tambahan bensin sehingga menjadi biofuel. Produksi etanol dunia untuk bahan bakar transportasi meningkat 3 kali lipat dalam kurun waktu 7 tahun, dari 17 miliar liter pada tahun 2000 
menjadi 52 miliar liter pada tahun 2007. Dari tahun 2007 ke 2008, komposisi etanol pada bahan bakar bensin di dunia telah meningkat dari $3.7 \%$ menjadi $5.4 \%$. Penelitian ini bertujuan untuk mengkaji proses pembuatan bioetanol dari kulit pisang kepok dan menganalisa kadar bioetanol yang dihasilkan.

\section{Bahan dan Metode}

Bahan dan peralatan yang diperlukan dalam penelitian ini diantaranya kulit pisang kepok, ragi roti, aquades, gula, urea, $\mathrm{NPK}, \mathrm{CaO}, \mathrm{HCl}, \mathrm{NaOH}$ dan seperangkat alat distilasi.

Penelitian ini terdiri atas lima tahap yaitu tahap hidrolisis, tahap persiapan/penumbuhan starter, tahap fermentasi, tahap distilasi dan tahap analisa. Variasi penelitian dilakukan terhadap perubahan volume starter dan waktu fermentasi. Adapun bagan penelitian dapat dilihat pada Gambar 2.

Tahap hidrolisis dilakukan dengan menghaluskan 300 gr kulit pisang kepok lalu dipanaskan sampai mendidih dengan menambahkan $\mathrm{HCl} 5 \%$ selama 60 menit.Tahap persiapan starter diawali dengan membuat larutan gula dengan kadar gula 14\% lalu dimasukkan kedalam tempat pembiakan, ditambahkan pupuk urea sebanyak $0.5 \%$ dari kadar gula yang digunakan, ditambahkan pupuk NPK sebanyak $0.1 \%$ dari kadar gula yang digunakan, ditambahkan ragi roti sebanyak 0,2\% dari kadar gula, lalu ditutup rapat dan disimpan dalam ruangan gelap dengan suhu kamar selama 24 jam. (Isroy, 2009). Tahap fermentasi diawali dengan menambahkan starter sesuai variabel yaitu (50, 150, 250 dan 350) ml dengan waktu fermentasi 3,5 dan 7 hari. Hasil fermentasi disaring untuk memisahkan ampasnya, kemudian dilakukan proses distilasi untuk memisahkan bioetanol dengan air pada suhu $80^{\circ} \mathrm{C}$ selama 60 menit, lalu hasil distilasi dilakukan analisa yield, serta kadarbioetanol yang dihasilkan 


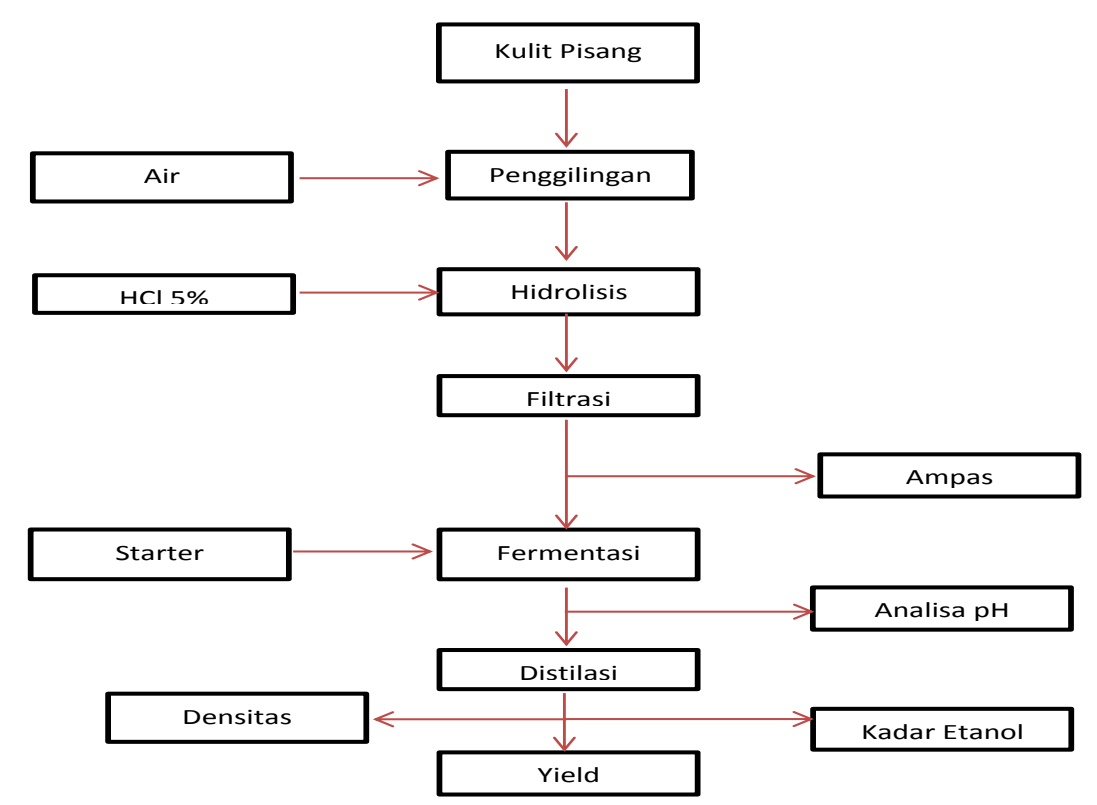

Gambar 2. Skema Proses Pembuatan Bioetanol dari Kulit Pisang Kepok

\section{Hasil dan Diskusi}

\subsection{Pengaruh Volume Starter Terhadap Kadar Bioetanol}

Pertumbuhan mikroorganisme terjadi dalam 3 fase, yaitu fase awal, fase eksponensial, dan fase stasioner. Fase awal merupakan periode adaptasi yakni sejak inokulasi pada medium dilakukan. Selama fase ini massa sel dapat berubah tanpa adanya perubahan jumlah sel. Setelah perubahan massa selanjutnya pertumbuhan mikroorganisme bergerak kearah fase eksponensial dimana terjadi perubahan sangat cepat terhadap jumlah sel. Kondisi ini tergantung terhadap konsentrasi nutrient yang ada. Ketika kondisi nutrient mulai habis, maka pertumbuhan mikrooranisme pun mulai berhenti. Kondisi berlanjut hingga mencapai suatu keadaan transisi kearah laju pertumbuhan nol yaitu fase stasioner (Said, 1987). Proses penguraian glukosa menjadi bioetanol terjadi pada fase eksponensial, dikarenakan mikroba tumbuh dengan sangat pesat pada fase tersebut sehingga proses penguraian glukosa semakin cepat dan mulai berhenti pada saat kondisi nutrien/subtrat mulai habis. 


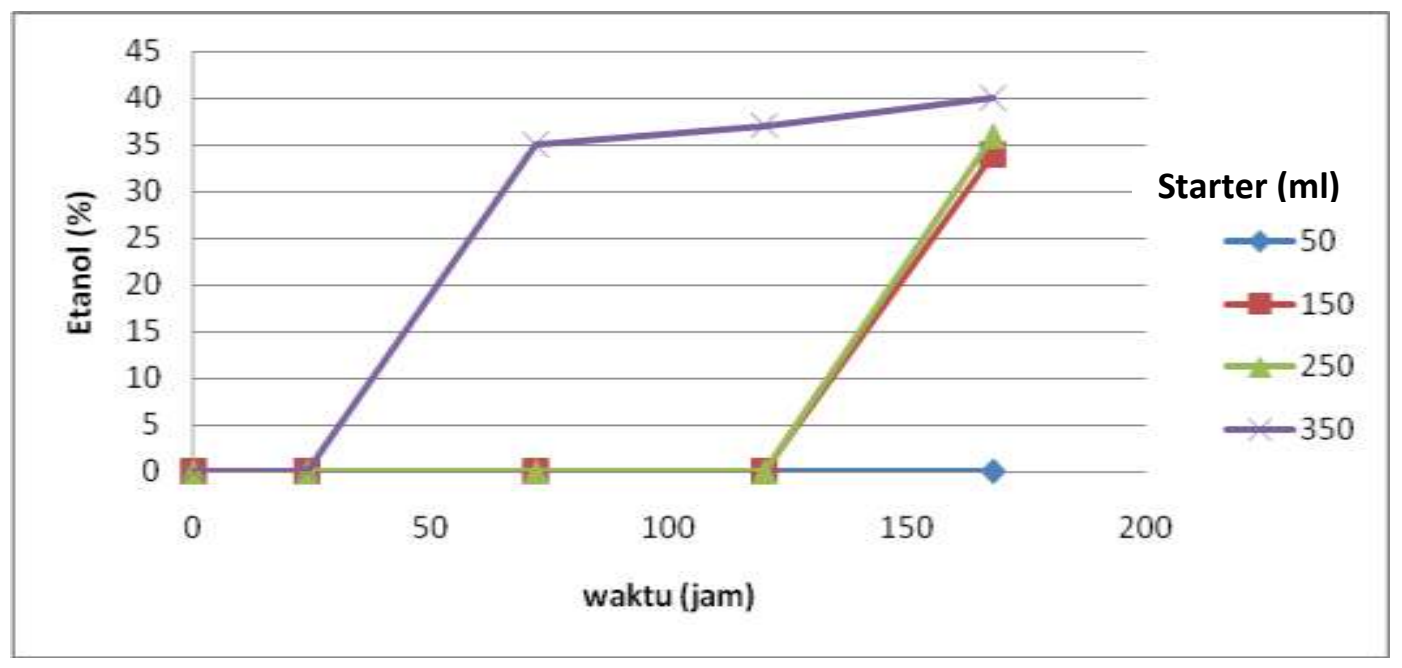

Gambar 3 Grafik Pengaruh Volume Starter Terhadap Kadar Bioetanol

Gambar 3 menunjukkan bahwa semakin besar volume starter yang digunakan maka bioetanol yang dihasilkan akan semakain banyak. Pada sampel dengan penambahan starter $50 \mathrm{ml}$ tidak diperoleh bioetanol dari hasil fermentasi selama 168 jam. Sedangkan pada sampel dengan volume starter yang diberikan $350 \mathrm{ml}$ bioetanol sudah terbentuk pada waktu fermentasi 72 jam dan semakin bertambah pada 120 jam dan 168 jam dengan kadar etanol tertinggi yaitu $40 \%$. Pada sampel dengan volume starter $150 \mathrm{ml}$ dan sampel 250 butuh waktu lama untuk menghasilkan bioetanol yaitu hingga pada hari terakhir yaitu 168 jam.

\subsection{Pengaruh Yield Terhadap Bioetanol}

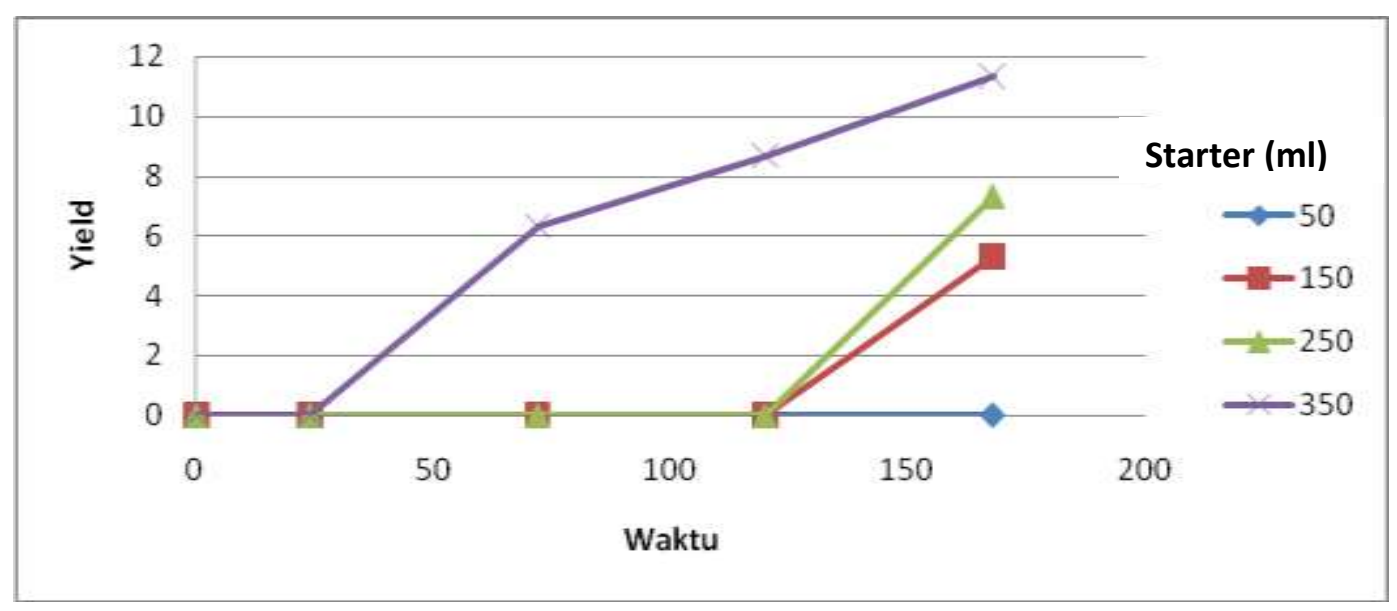

Gambar 4. Grafik Pengaruh Yield Terhadap Bioetanol 
Pada Gambar 4 dapat dilihat yield yang dihasilkan dengan semakin bertambahnya volume starter yang digunakan maka semakin tinggi pula yield yang diperoleh. Dari grafik dapat kita lihat bahwa yield tertinggi diperoleh sampel dengan volume starter terbanyak $350 \mathrm{ml}$ dengan yield yang dicapai yaitu 11,33\%.

\subsection{Analisa Gas Chromatography}

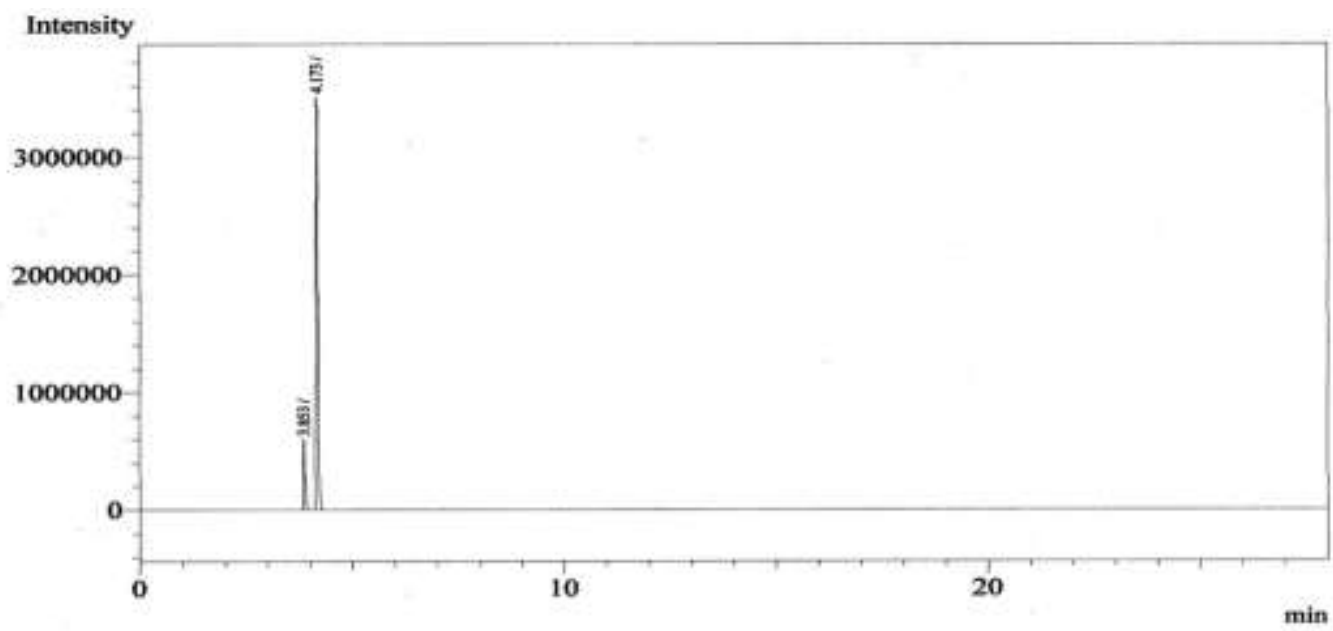

Gambar 5 Grafik HasilAnalisa Bioetanol dengan menggunakan Gas Chromatography

Bioetanol diuji menggunakan alat gas chromatography untuk melihat senyawa yang terdapat pada sampel. Pada pengujian pertama dimenit 3,853 terbaca gelombang dengan tinggi $602504 \mu \mathrm{m}$ dan luas area $1810908 \mu \mathrm{m}$ berupa metanol dengan konsentrasi $13,772 \%$. Dan pada pengujian kedua terbaca gelombang kedua dengan tinggi $3504353 \mu \mathrm{m}$ dan luas area $11337902 \mu \mathrm{m}$ berupa etanol dengan konsentrasi $86,228 \%$. Pada pengujian selanjutnya tidak ditemukan gelombang ketiga hingga akhir pengujian.

Gambar 5 memperlihatkan bahwa tidak ada senyawa kimia lain yang terdapat pada bioetanol yang dihasilkan dari kulit pisang kepok. Produksi bioetanol dengan metode fermentasi hanya menghasilkan bioetanol dan gas karbon dioksida, tidak ada senyawa lain yang dihasilkan jika reaksi fermentasinya berlangsung secara sempurna. Dalam proses fermentasi terkadang akan menghasilkan senyawa metanol dalam jumlah yang tidak terlalu signifikan, 
senyawa tersebut tidak mengganggu kualitas bioetanol karena jumlahnya yangsedikit dan sama-sama dapat digunakan sebagai bahan bakar mesin bermotor.

\section{Kesimpulan}

1. Sampel dengan penggunaan volume starter sebanyak $350 \mathrm{ml}$ pada waktu fermentasi 7 hari mengghasilkan kadar etanol tertinggi yaitu $40 \%$.

2. Selain etanol juga terbentuk metanol dengan jumlah yang sangat sedikit sebagai hasil produk samping proses fermentasi dari kulit pisang kepok.

\section{Daftar Pustaka}

Agus Krisno Budiyanto, M.Kes, (2011), "Pertumbuhan Microorganisme" Pendidikan Biologi UMM.

Arif Yudiarto, (2011), Balai Besar Teknologi Pati (B2TP) - BPPT Lampung..

Asteria, Apriliani.S, Franky, Agustinus (2013), "Pembuatan Etanol Dari Kulit Pisang Secara Fermentasi", Jurusan Teknik Kimia Fakultas Teknik Universitas Diponegoro,Semarang.

Dyah, Tri Retno. Wasir, Nuri, (2011), "Pembuatan Bioetanol Dari Kulit Pisang", Jurusan Teknik Kimia Fakultas Teknik Industri UPN"Veteran",Yogyakarta.

Isroy, (2009), “Membuat Bensin Sendiri Dari Sisah Minuman Bekas”artikel.

Khairani, (2006), “Pembuatan Etanol Dari Sirsak Secara Fermentasi”,Jurusan Teknik Kimia Fakultas Teknik Universitas Malikussaleh,Lhokseumawe.

Kusnoputranto H. (1996). "Toksikologi Lingkungan Logam Toksik dan B3" Jakarta: UI-Press.

Nityasa M H Y T, Hafidh Frian P, Nur Hasanah, Dr. Widyastuti, S.Sc., M.Sc (2006), "Pemanfaatan Kulit Pisang Sebagai Bahan Baku Bioetanol Berbasis Fermentasi”.Institut Teknologi Sepuluh Nopember (ITS), Surabaya.

Saroso, Hadi, (1998), "Pemanfaatan Kulit Pisang Dengan Cara Fermentasi untuk Pembuatan Alkohol”, Teknik Kimia Politeknik Universitas Brawijaya, Malang.

Soedarmadji, (2002), "Diktat Kuliah Mikrobiologi Industri", Jurusan Teknik Kimia Fakultas Teknik Universitas Diponegoro,Semarang. 
Wusnah, dkk / Jurnal Teknologi Kimia Unimal 8 : 1 (Mei 2019) 48 - 56

Kurniawan, T.N., 2009, “Pembuatan Bioetanol Dari Nira Aren”,Jurusan

Teknik

Kimia

Fakultas

Teknik

Universitas

Malikussaleh,Lhokseumawe. 